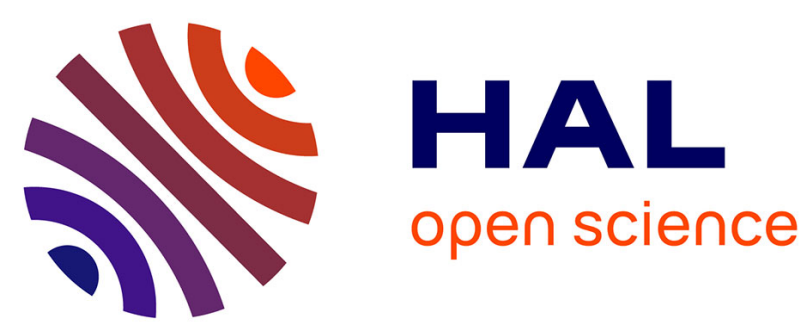

\title{
Technology of Medieval Mortars: An Investigation into the Use of Organic Additives
}

Laura Rampazzi, M. P Colombini, C. Conti, C. Corti, A. Lluveras-Tenorio, A. Sansonetti, And M Zanaboni

\section{- To cite this version:}

Laura Rampazzi, M. P Colombini, C. Conti, C. Corti, A. Lluveras-Tenorio, et al.. Technology of Medieval Mortars: An Investigation into the Use of Organic Additives. Archaeometry, 2016, 58 (1), pp.115 - 130. 10.1111/arcm.12155 . hal-01705544

\section{HAL Id: hal-01705544 \\ https://hal.science/hal-01705544}

Submitted on 9 Feb 2018

HAL is a multi-disciplinary open access archive for the deposit and dissemination of scientific research documents, whether they are published or not. The documents may come from teaching and research institutions in France or abroad, or from public or private research centers.
L'archive ouverte pluridisciplinaire HAL, est destinée au dépôt et à la diffusion de documents scientifiques de niveau recherche, publiés ou non, émanant des établissements d'enseignement et de recherche français ou étrangers, des laboratoires publics ou privés. 


\title{
Technology of medieval mortars: an investigation into the use of organic additives
}

\author{
L. Rampazzi ${ }^{1 *}$, M. P. Colombini ${ }^{2}$, C. Conti $^{3}$, C. Corti ${ }^{1}$, A. Lluveras-Tenorio ${ }^{2}$, \\ A. SANSONETTI ${ }^{3}$ AND M. ZANABONI ${ }^{2}$
}

1Dipartimento di Scienza e Alta Tecnologia, Università dell'Insubria, via Valleggio 11, 22100 Como, Italy 2Dipartimento di Chimica e Chimica Industriale, Università di Pisa, Via Risorgimento 35, 56126 Pisa, Italy 3Istituto per la Conservazione e la Valorizzazione dei Beni Culturali, Consiglio Nazionale delle Ricerche,Unità di Milano 'Gino Bozza', Area della Ricerca Milano 3 Bicocca, via Cozzi 53, 20125 Milano, Italy

*Corresponding author

Laura Rampazzi, email address: laura.rampazzi@uninsubria.it; phone number: +390312386475; fax number: +390312386449

\begin{abstract}
This work proposes a multi-analytical approach to determine the additives in historical mortars, the use of which is widely described in bibliographical sources, but has rarely been reported in the literature. A protocol to thoroughly analyse mortars was created (optical microscopy, X-ray diffraction, infrared spectroscopy, thermal analyses and gas chromatography - mass spectrometry). These techniques had already been carried out on samples from various sites from the Roman to the modern era, finding that additives had only been used in the mortars from the internal masonry at our sampling site: the medieval military shipyard of Amalfi (Italy). The investigations yielded information on the production technology, and FT-IR and GC-MS revealed a saccharide material-based additive in the mortars, of plant origin. The FT-IR spectra suggested the presence of a natural gum, which has been used since ancient times to strengthen the cohesion properties of mortars and their resistance to tensile stress.
\end{abstract}

Keywords: Amalfi, medieval mortars, organic additives, infrared spectroscopy, thermal analysis, microscopic analyses, gas chromatography - mass spectrometry, mortar technology

\section{INTRODUCTION}

The most common components of historical mortars are known through the bibliographical sources on ancient technologies. A wide number of scientific papers have confirmed calcium carbonate as the most common binder component, together with a hydraulic binder, and usually with sand being the main aggregate phase. The use of additives in mortars has rarely been reported in papers on conservation science or the history of technology. Most of the literature focuses on the addition of organic compounds to the mortar paste for various purposes (Sickels 1981; Arcolao 1998; Carbonara 2007). In the past few years, we have analysed a large number of historical mortars (architectural mortars and stuccoes) from various sites, dating from Roman times to the modern era (Bugini et al. 2006; Rampazzi and Bugini 2006; Corti et al. 2013; Bugini et al. 2014). The aim of our multi-analytical approach (Rampazzi et al. 2010) is to shed light on the main features of mortars; that is, the composition of the binder and aggregate fractions, the morphology and structure, the binder/aggregate ratio and the mineralogical phases. Using this approach, we have previously studied the organic phases, and in the case of Baroque stuccoes, an egg-based additive was successfully 
characterized by combining spectroscopic and chromatographic techniques (Rampazzi et al. 2008, 2012). In the current study, we found organic additives in mortars from the brick bedding in the masonry at our archaeological site in Amalfi (Italy) - a medieval shipyard/ building, known in Italian as Arsenale (which is not to be confused with the English word 'arsenal').

The Amalfi Arsenale is the only surviving example of a medieval shipyard in southern Italy (Gargano 1994). The ships and galleys were constructed in a building dating back to the ninth century, the ruins of which still remain. The grandiose Gothic construction was located on the waterfront, to the left of the 'Porta della Marina', and extended as far as the quay. It was renovated in 1240 and 1272, and was partially destroyed during a devastating sea-storm in 1343 . The need to build using a mortar that was resistant to high humidity levels and sea salt spray had to be considered by the ancient builders. The need to use mortars with organic additives may have arisen due to this issue. Ten pillars divide the Arsenale into two stone brick passages (Fig. 1), with only 12 pointedarch arcades still standing out of the 22 that had originally opened out towards the sea (Gargano 1994). The building is currently $44.60 \mathrm{~m}$ long and $6.65 \mathrm{~m}$ wide. The blocks of stone of the interior walls are joined together by a bedding mortar, which was sampled and analysed. The bedding mortars are whitish in colour and irregular in shape and thickness, the latter varying between 2 and $4 \mathrm{~cm}$; the texture of the mortar is rough and the presence of organic additives cannot be discerned from its appearance.

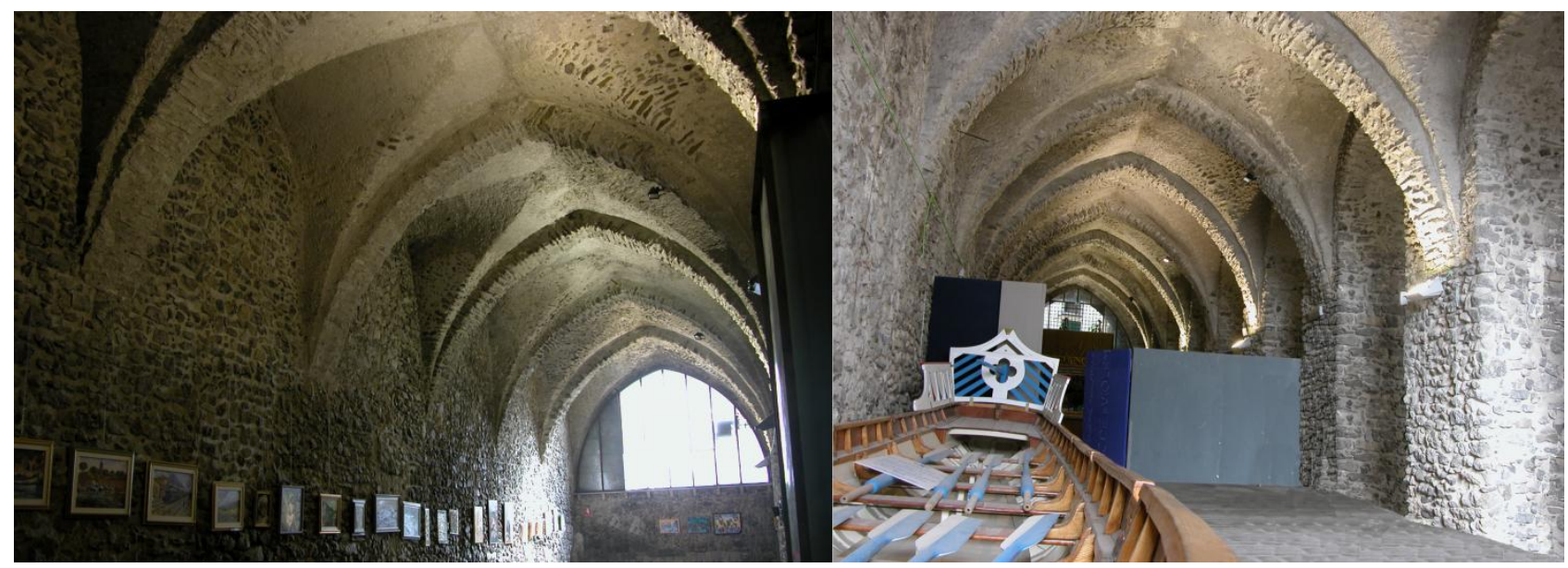

Figure 1 The Arsenale of Amalfi: details of the stone brick passages.

This was an opportunity to shed light on the building techniques and medieval engineering, and to verify the recipe for the mortar mix of the historical masonry. Also, attempts to highlight the presence of organic substances were planned in the analytical survey.

The literature (Sickels 1981; Carbonara 2007) reports the use of additives with varying aims:

- improving the durability and hardness;

- reducing the drying shrinkage;

- increasing the resistance to traction;

- delaying/accelerating the setting time;

- facilitating adhesion on to the surface;

- stabilizing any emulsion, if present;

- increasing resistance to decay caused by freeze/thaw cycles; and

- increasing the plasticity and workability.

The use of organic compounds dates back to ancient times and became common in Europe in the medieval epoch under Byzantine influence. Pliny the Elder in his Naturalis historia and Vitruvius in his De architectura mention that the 
Romans commonly used additives in order to enhance the resistance of mortars (Pliny 1968; Vitruvius 1999). The most common additives were animal glue, casein and other dairy products, beer, animal fat, linseed oil, albumen, blood and natural resins (Sickels 1981; Pecchioni et al. 2008). Pliny mentions a special mortar called 'maltha', composed of lime slaked in wine, hogs' lard and fig juice, and designed for wet rooms, such as thermal baths (Arcolao 1998). Cennino Cennini, in his Il libro dell'arte, describes a mortar produced with lime putty and cheese, which adhered extremely well to stone blocks (Cennini 2009). In the 18th century, Francesco Milizia reports a similar mixture, with the addition of oil in order to enhance the impermeability of mortars used in aqueducts and cisterns (Arcolao 1998). The organic products mentioned above were used without any specific knowledge of their properties in the recipe for the mix and the performance they were able to induce. Most probably, they were simply added, making use of local resources, after which the resulting performance was observed empirically. Carbohydrate-based materials such as malt, sugar, molasses and gum arabic were also often used. Lime and sugar derivates react quickly to form calcium saccharate, which strengthens the cohesion properties of the mortars and the traction resistance, especially in a warm and dry climate and in the case of large masonry, where the lime sets slowly (Carbonara 2007). Cardenas and co-workers investigated the role of polysaccharides in lime mortars also mixed with nopal (Cardenas et al. 1998). Cactus juice was commonly added to mortars in historical Mexican buildings, to improve the performance against water penetration and cracking.

Cardenas demonstrated that the mechanical properties increased due to the formation of an interpenetrated network of cactus polysaccharide mucilage and $\mathrm{Ca}(\mathrm{OH})_{2}$. In the 17th century, fir pine cones were added to mortars: the tannin and sugar content of the cones ensured water resistance and the plasticity of the paste (Arcolao 1998). As far as modern mortars are concerned, additives are again used both to slow down and accelerate the setting time, and to increase the workability (Pecchioni et al. 2008). When added to repair mortars, cactus gum increased the mechanical performance (Alonso et al. 2002) and the carbonation front (Ventola et al. 2011). The plasticity and resistance of Portland cement are also increased when it is mixed with cactus extract, due to the formation of complexes with $\mathrm{Ca}(\mathrm{OH})_{2}(\mathrm{Chandra}$ et al. 1998).

Despite the above-mentioned investigations, to the best of our knowledge the determination of additives in historical mortars has rarely been documented. By extraction treatment with chloroform-ethanol and infrared analysis, Luxan et al. (1995) identified the presence of wax, resin and drying oil in ancient gypsum mortars from the St Engracia Basilica (16th century, Zaragoza, Spain). Elsewhere, HPLC analyses have pointed to the use of egg white in Byzantine lime mortars (Kurugol and Gulec 2012). Kuckova identified proteinaceous compounds in Romanesque mortars by peptide mass mapping and mass spectrometry analyses (Kuckova et al. 2009). The same authors also set up two efficient spectrometric methods to analyse protein additives in mortars (Krizkova et al. 2014). Sticky rice has been determined in 18th-century mortars (Zeng et al. 2008), while Duran et al. (2008) have highlighted the presence of cellulosic materials from fibres in mortars dating back to the 16th-17th centuries. Plant gums have been identified by ion chromatography in Macedonian tombs (Greece) wall paintings of the fourth to third centuries BC (Colombini et al. 2002).

The composite nature of bedding mortars is normally investigated by an integrated protocol of analyses, since a complementary approach is strongly recommended for reliable and complete results on the binder and aggregate fractions. X-ray diffraction (XRD) analysis and optical microscopy (OM) highlight the mineralogical phases. Fourier transform infrared spectroscopy (FT-IR) spectra determine the nature of the inorganic compounds and of the organic additive. Thermogravimetric analysis and differential scanning calorimetry (TG/DSC) determine organic compounds and quantify the binder used in the preparation of the mortar, indirectly determining the binder/aggregate ratio, while gas chromatography - mass spectrometry (GC-MS) identifies the organic phases. The analyses also help to verify the state of conservation of the mortars, determining decay markers such as efflorescences and gypsum. In this survey, the 
abovementioned techniques constituted a multi-analytical protocol for the characterization of the mortars from the Arsenale in Amalfi.

\section{MATERIALS AND METHODS}

The samples were collected by using a scalpel, according to the indications of UNI-Normal 3/80 (CNR-ICR 1980). Figure 2 shows the location of the samples. Small fragments of each one were analysed as polished cross-sections and thin sections.

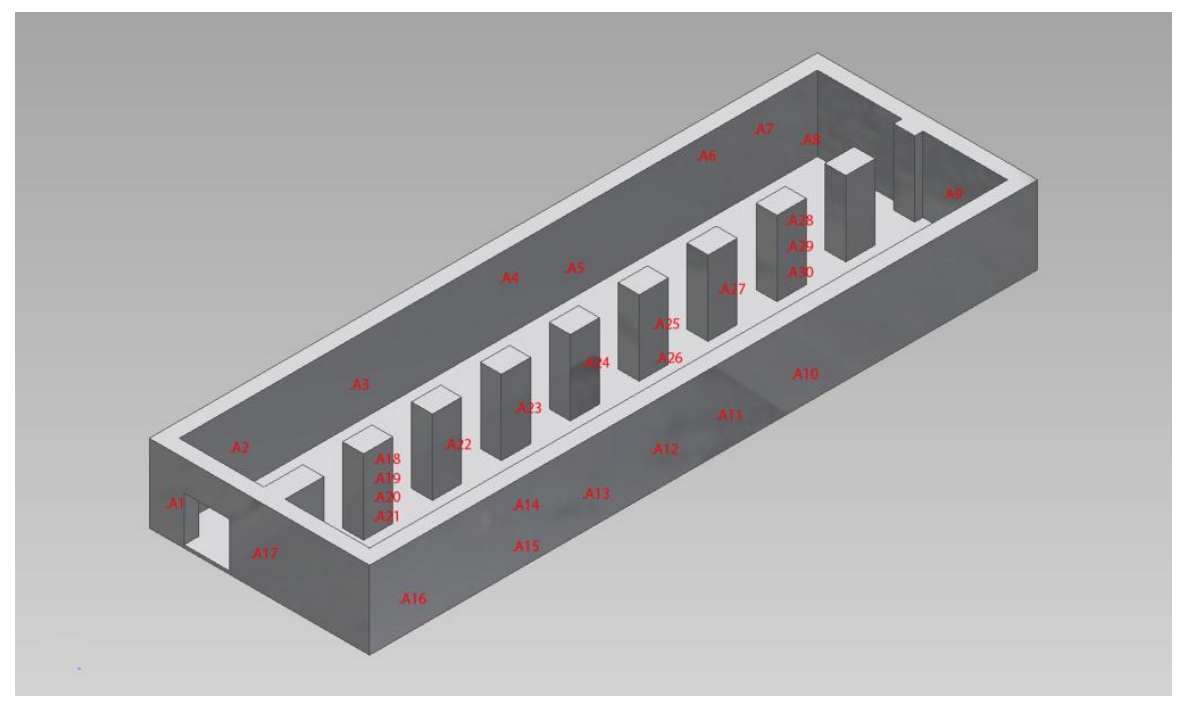

Figure 2 The location of the mortar samples

\section{Optical microscopy}

Preliminary morphological observations were carried out on micro-fragments using a LeitzWild M420 stereomicroscope. Thin cross-sections (30 $\mu \mathrm{m}$ thick) of the samples were observed in reflected light using a Leitz Ortholux microscope with an Ultropack illuminator, and in polarized light using a Nikon Eclipse E400Pol microscope. All microscopes were equipped with a digitalimage capture system.

\section{$X$-ray diffraction}

Fine powders of the samples were analysed using a Bruker AXS D8 ADVANCE diffractometer with the following conditions: generator settings $40 \mathrm{kV}$ and $40 \mathrm{~mA}$; fenditure divergence slit 1.0; RS $0.2 \mathrm{~mm}$; $R=217.5 \mathrm{~mm}$; radiation $\mathrm{Cu}-\mathrm{K}_{\alpha}, \lambda=1.5418 \AA$; pyrolytic graphite monochromator with diffracted ray; geometry $\theta: \theta$; soller slits $2.3^{\circ}$; continuous

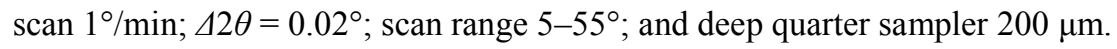

\section{Fourier transform infrared spectroscopy}

The samples were analysed as KBr (Sigma-Aldrich FT-IR Grade) pellets using a BioRad Excalibur Series FTS 3000 FT-IR spectrophotometer and a DTGS detector, in the transmission mode (400-4000 cm-1, 4 cm-1 resolution, 16 scans). Regarding the extraction protocol, around $50 \mathrm{mg}$ of the fine powders of the samples were put in a glass test tube, completely dipped into organic solvents (around $0.5 \mathrm{~mL}$ ) and sonicated for $15 \mathrm{~min}$. The extractions were conducted using hexane (Sigma-Aldrich 95\% anhydrous), toluene (Sigma-Aldrich 99.8\% anhydrous) and ethyl acetate (Sigma- 
Aldrich 99\% anhydrous), in order to extract non-polar and polar components, respectively (Doménech Carbó et al. 1996; Derrick et al. 1999; Colombini et al. 2003). The test tubes were centrifuged for 3 min. The soluble fraction was placed on a $\mathrm{NaCl}$ plate and analysed in the transmission mode after gentle evaporation of the solvent. Solvent blanks were prepared to check for contaminations. Extractions with deionized water (MilliQ Millipore grade) were also carried out. The soluble fraction was placed on a watch glass and left to evaporate. The residue was analysed as $\mathrm{KBr}$ pellets.

\section{Thermal analysis}

Determinations were performed using a NETZSCH STA 409 PC. Samples were placed in alumina crucibles, and the temperature programme ranged from room temperature to $900^{\circ} \mathrm{C}$, at a heating rate of $10^{\circ} \mathrm{C}$ min-1 under a pure nitrogen atmosphere. Raw data from thermogravimetric analysis (TG) and differential scanning calorimetry (DSC) were corrected on the basis of a background curve.

\section{Gas chromatography - mass spectrometry analysis}

Various selected samples were analysed according to a complex analytical procedure that characterizes all the organic compounds from the same microsample, avoiding interferences from inorganic media (Lluveras et al. 2010). The system used was a 6890N GC System Gas Chromatograph from Agilent Technologies, coupled with a 5975 Mass Selective Detector (also Agilent Technologies) with a single quadrupole mass spectrometer equipped with a PTV injector. The mass spectrometer operated in the electron impact (EI) positive mode (70 eV). The MS transfer line temperature was $280^{\circ} \mathrm{C}$, the MS ion source temperature was kept at $230^{\circ} \mathrm{C}$ and the MS quadrupole temperature was $180^{\circ} \mathrm{C}$. The samples were digested in a Milestone MLS-1200 MEGA microwave oven. The acidic hydrolysis of proteins was performed using powers of $250 \mathrm{~W}$ for $10 \mathrm{~min}$ and $500 \mathrm{~W}$ for 30 minutes, with $30 \mathrm{~mL}$ of $6 \mathrm{~N} \mathrm{HCl}$ at $160^{\circ} \mathrm{C}$ for $40 \mathrm{~min}$. The acidic hydrolysis of polysaccharides was performed using a power of $500 \mathrm{~W}$ for $20 \mathrm{~min}$, at $120^{\circ} \mathrm{C}$, with $500 \mathrm{~mL}$ of TFA $2 \mathrm{M}$. Saponification was performed using a power of $200 \mathrm{~W}$ for $60 \mathrm{~min}$ at $80^{\circ} \mathrm{C}$, with $300 \mathrm{~mL}$ of $\mathrm{KOH}$ in EtOH $10 \mathrm{wt} \%$. The detailed analytical procedure and operating conditions are described elsewhere (Lluveras et al. 2010). The detection (LOD) and the quantification (LOQ) limits of amino acids, aldoses, uronic acids and fatty and dicarboxylic acids were calculated at a statistical significance level of 0.05 and used for the quantitative evaluation of each fraction. The LODs of the proteinaceous, lipid and saccharide materials were $0.35,1.22$ and $0.64 \mu \mathrm{g}$, respectively. The LOQs of the proteinaceous, lipid and saccharide materials were $0.75,1.47$ and $1.48 \mu \mathrm{g}$, respectively.

\section{RESULTS AND DISCUSSION}

\section{Mortar investigation}

Although our focus was on organic additives, we also made a complete characterization of the mortar. In fact, combining the analysis of the inorganic fraction with the organic added substances enabled us to better understand the design criteria for the mortar mix. The mineralogical characterization of the mortars was performed by comparing the results achieved with X-ray diffractometry (Table 1) and polarized microscopy observations (Fig. 3). On the basis of the XRD results, samples were selected for the preparation of thin sections. Each mortar showed a high binder/aggregate ratio, with the aerial binder mainly consisting of calcite $\left[\mathrm{CaCO}_{3}\right]$, even though there was frequently a small quantity of magnesium carbonates as nesquehonite $\left[\mathrm{Mg}\left(\mathrm{HCO}_{3}\right)(\mathrm{OH}) \cdot 2\left(\mathrm{H}_{2} \mathrm{O}\right)\right]$, magnesite $\left[\mathrm{MgCO}_{3}\right]$ and dolomite $\left[\mathrm{MgCa}\left(\mathrm{CO}_{3}\right)_{2}\right]$. The wide variety of carbonates could be ascribed to the geological features of the area, which are characterized by 
Liassic limestones and dolomites. The aggregate was exclusively silicatic, consisting mainly of feldspathoids as analcime $\left[\mathrm{NaAlSi}_{2} \mathrm{O}_{6} \cdot \mathrm{H}_{2} \mathrm{O}\right]$ and leucite $\left[\mathrm{K}\left[\mathrm{AlSi}_{2} \mathrm{O}_{6}\right]\right]$. These minerals are commonly found in volcanic rocks enriched in alkaline elements; in fact, they occur in the most abundant Monte Somma-Vesuvio lavas, together with augite $\left[\left(\mathrm{Ca}, \mathrm{Mg}, \mathrm{Fe}_{2+}, \mathrm{Fe}_{3+}, \mathrm{Ti}, \mathrm{Al}\right)_{2}(\mathrm{Si}, \mathrm{Al})_{2} \mathrm{O}_{6}\right]$ and olivine $\left[(\mathrm{Mg}, \mathrm{Fe})_{2} \mathrm{SiO}_{4}\right]$.

\begin{tabular}{|c|c|c|c|c|c|c|c|c|}
\hline Sample label & Calcite & Mg-Carbonates & Quartz & Feldspathoids & K-feldspars & Muscovite & Gypsum & Halite \\
\hline A1 & +++ & + & - & ++ & - & + & - & +++ \\
\hline A2 & +++ & - & - & + & ++ & ++ & - & +++ \\
\hline A3 & +++ & ++ & - & + & - & - & - & ++ \\
\hline A4 & +++ & - & - & + & + & - & + & - \\
\hline A5 & +++ & + & - & + & + & - & - & + \\
\hline A7 & +++ & + & - & + & - & + & - & + \\
\hline A8 & +++ & $+/-$ & + & + & - & + & - & + \\
\hline A9 & +++ & + & - & ++ & - & - & - & - \\
\hline $\mathbf{A 1 0}$ & +++ & + & - & + & ++ & - & - & - \\
\hline A11 & +++ & $+/-$ & - & - & - & - & ++ & + \\
\hline A12 & +++ & ++ & - & + & - & - & - & + \\
\hline $\mathbf{A 1 3}$ & ++ & +++ & - & + & - & - & - & + \\
\hline A14 & +++ & - & - & +++ & - & - & + & + \\
\hline $\mathbf{A 1 5}$ & +++ & + & - & ++ & - & - & - & + \\
\hline A16 & +++ & - & - & - & - & - & - & $+/-$ \\
\hline A17 & +++ & ++ & - & +++ & + & - & - & +++ \\
\hline A18 & +++ & ++ & - & + & - & - & - & +++ \\
\hline A19 & +++ & + & - & ++ & - & +++ & - & - \\
\hline A20 & +++ & ++ & - & - & - & + & - & +++ \\
\hline A22 & +++ & ++ & + & + & - & + & - & ++ \\
\hline $\mathbf{A 2 3}$ & +++ & $+/-$ & + & ++ & - & + & - & ++ \\
\hline A24 & +++ & + & - & ++ & + & - & - & ++ \\
\hline A25 & +++ & + & - & ++ & - & - & - & ++ \\
\hline A26 & +++ & + & - & ++ & - & + & - & ++ \\
\hline A27 & +++ & ++ & - & + & + & - & - & ++ \\
\hline A28 & +++ & + & - & ++ & - & - & - & - \\
\hline A29 & +++ & - & + & + & - & ++ & - & - \\
\hline A30 & +++ & + & - & ++ & - & - & - & - \\
\hline
\end{tabular}

Table 1 X-ray diffraction semiquantitative data. [Legend: +++ very abundant $(>40 \%) ;++$ abundant $(15-40 \%):+$ present $(3-15 \%) ;+/-$ scarce $(<3 \%)$ ] 
The occurrence of forsterite $\left[\mathrm{Mg}_{2} \mathrm{SiO}_{4}\right]$, the magnesium-rich end-member of the olivine solid solution series, verified by examining thin sections, confirmed the use of a volcanic aggregate belonging to the Monte Somma-Vesuvio lavas for the preparation of the mortars. Although to a lesser extent, the aggregate was also characterized by more common minerals such as $\mathrm{K}$-feldspars $\left[\mathrm{KAlSi}_{3} \mathrm{O}_{8}\right]$, muscovite $\left[\mathrm{KAl}_{2}\left(\mathrm{AlSi}_{3} \mathrm{O}_{10}\right)(\mathrm{F}, \mathrm{OH})_{2}\right]$ and quartz $\left[\mathrm{SiO}_{2}\right]$.

Two granulometric fractions of aggregate were measured: quartz and feldspars have a finer granulometry, ranging from 0.1 to $0.3 \mathrm{~mm}$; feldspathoids and forsterites show a coarser size, from 1 to $4 \mathrm{~mm}$. Neither natural pozzolan nor other hydraulic additives have been detected. Some decay products were determined, such as gypsum $\left[\mathrm{CaSO}_{4} \cdot 2 \mathrm{H}_{2} \mathrm{O}\right]$ and halite $[\mathrm{NaCl}]$. The first is probably caused by the sulphation process of the lime binder fraction; the latter is clearly due to the close proximity to the seashore. The pattern of XRD and the observations of the thin sections did not provide any evidence of organic substances in the mix.

The detection of quartz in the pillar mortars proves that in these samples. another kind of aggregate (sand) was used together with the volcanic fragments. In fact, it is well known that the co-presence in rocks of quartz and feldspathoids is not possible. The use of a sand aggregate was probably due to the need to enhance the mechanical resistance of the mortar.
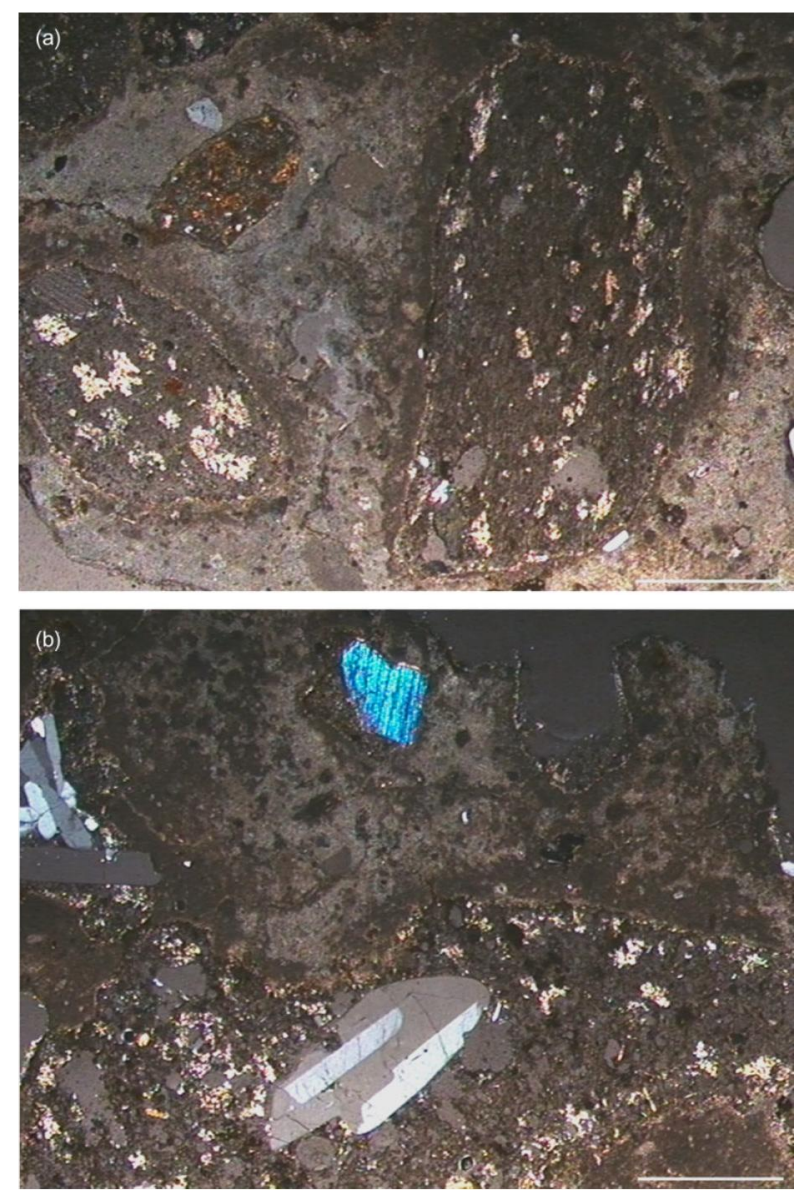

Figure 3 A thin section micrograph of the mortars observed in crossed polarised light: (a) sample A29; (b) sample A14. The main components of the mortar aggregates are feldspathoids, the coarse grains clearly visible in (a); olivine, the crystal with high interference colours in the upper part of (b); quartz and feldspars, with their low order interference colours, visible both in (a) and (b) (bar=1 mm).

Infrared spectra confirmed the XRD results as far as calcite and silicates are concerned. Analyses by medium infrared spectroscopy can rarely determine the silicate family; thus it is not possible to discriminate between the different phases highlighted with the mineralogical investigations. The presence of calcite was suggested by the asymmetric $\mathrm{C}-\mathrm{O}$ stretching band between 1430 and $1440 \mathrm{~cm}^{-1}$ and by the absorbances at 874 (out-of-plane bending vibration), 713 (in- 
plane bending vibration), 1798 and $2514 \mathrm{~cm}^{-1}$ (combination modes). Silicates present bands in the regions of 1200-900 and $500-400 \mathrm{~cm}^{-1}$, due to their $\mathrm{SiO}_{4}$ tetrahedra. Gypsum was determined in low amounts only in a few samples, which showed characteristic peaks at 671 and $600 \mathrm{~cm}^{-1}$ (S-O bending bands). Some organic matter was found in all the samples, in most cases just as traces, with peaks in the regions around $2800-2900 \mathrm{~cm}^{-1}$-that is, C-H signals - and around $1650 \mathrm{~cm}^{-1}$. This suggested the presence of the carbonyl function, which is normally in the range $1680-1820 \mathrm{~cm}^{-1}$, but which could have been lowered by conjugation effects or by the presence of a calcium salt, probably calcium saccharate. We thus made further analyses in order to identify the organic compound. A preliminary FT-IR survey on organic solvent-soluble portions of the most meaningful samples was designed, so as to focus on the organic family for GC-MS analyses.

\section{Investigation of organic fraction}

Infrared spectroscopy (FT-IR) All the samples were extracted using various organic solvents, as described in the 'Materials and Methods' section, and the residues were analysed using a FT-IR spectrophotometer. Analyses of residues after extraction with hexane and toluene presented no absorbance peaks, except for not yet evaporated solvent. In contrast, spectra recorded after ethyl acetate extraction showed peaks typical of organic compounds. Generally, the $\mathrm{C}-\mathrm{H}$ bond is suggested by stretching and bending absorbance signals, respectively, at 2921 and $2854 \mathrm{~cm}^{-1}$. The stretching absorbances of $\mathrm{C}=\mathrm{O}$ and $\mathrm{C}-\mathrm{O}$ bonds were observed around $1635 \mathrm{~cm}^{-1}$ and $1230 \mathrm{~cm}^{-1}$, respectively. Figure 4 shows the spectrum of sample A27 after extraction with ethyl acetate. Some peaks are due to residues of the inorganic fraction; that is, calcite and silicates. Most samples left no residues after extraction with hot water, except for samples A7, A9, A15 and A23, the absorbance peaks of which are summarized in Table 2. The FT-IR spectra confirmed aliphatic $\mathrm{C}-\mathrm{H}$ stretches around $3000-2800 \mathrm{~cm}^{-1}$ and group $\mathrm{C}=\mathrm{O}$ stretching absorption around $1650 \mathrm{~cm}^{-1}$. Figure 5 presents the spectra recorded after extraction of sample A23 with water and ethyl acetate.

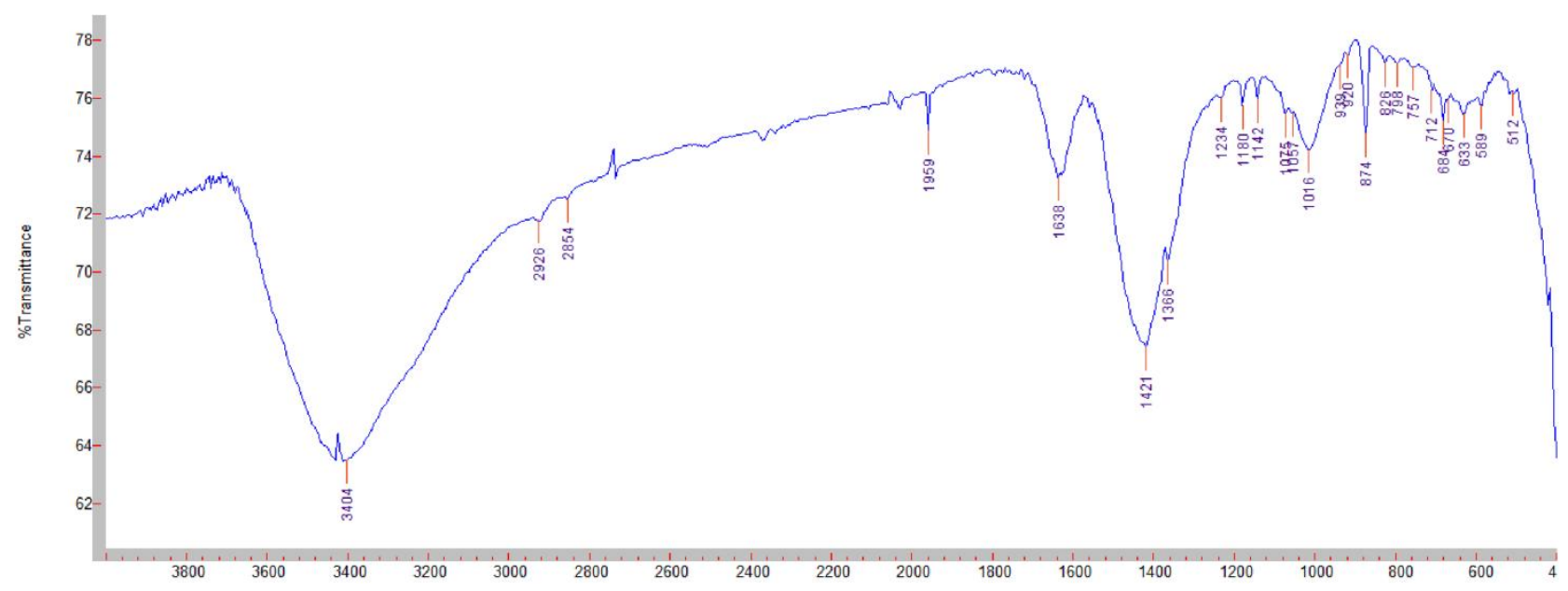

Figure 4 An FT-IR (infrared spectroscopy) transmission spectrum of sample A27 after extraction with ethyl acetate, showing the signals of calcite $\left(1421,874\right.$ and $712 \mathrm{~cm}^{-1}$ and organic compounds $\left(2926,2854,1638,1366,1234,1075\right.$ and $\left.920 \mathrm{~cm}^{-1}\right)$. 


\begin{tabular}{|l|l|l|l|l|l|}
\hline \multirow{3}{*}{ Sample label } & $\begin{array}{l}3600-3200 \mathrm{~cm}^{-1} \\
\text { stretching } \\
O-H\end{array}$ & $\begin{array}{l}3000-2800 \mathrm{~cm}^{-1} \\
\text { stretching } \\
C-H\end{array}$ & $\begin{array}{l}1650 \mathrm{~cm}^{-1} \\
\text { stretching } \\
C=O\end{array}$ & $\begin{array}{l}1480-1300 \mathrm{~cm}^{-1} \\
\text { bending } \\
C-H\end{array}$ & $\begin{array}{l}1300-900 \mathrm{~cm}^{-1} \\
\text { stretching } \\
C-O\end{array}$ \\
\hline $\mathbf{A 7}$ & 3415 & 1633 & 1384 & 920 \\
\hline A9 & 3418 & 2855 & 1633 & 1384 & \\
\hline $\mathbf{A 1 5}$ & 3423 & 2924,2855 & 1640 & 1383 & \\
\hline $\mathbf{A 2 3}$ & 3420,3240 & 2926,2855 & 1632 & 1384 & \\
\hline
\end{tabular}

Table 2 Infrared absorbance peaks of residue after extraction with water

The comparison with reference standards of aged organic binders and the spectra found in the literature (Derrick 1989; Cui et al. 2007) suggested that the samples obtained after extraction with water and ethyl acetate might contain polysaccharides. The strong bands around $3300 \mathrm{~cm}^{-1}$, ascribed to $\mathrm{O}-\mathrm{H}$ group stretching, and around $1080 \mathrm{~cm}^{-1}$, due to the $\mathrm{C}-\mathrm{O}$ fingerprint, are particular features of polysaccharides and usually have the same intensity. Other clues are the weak signals around 2800-3000 $\mathrm{cm}^{-1}$ (methyl and methylene symmetric and asymmetric stretching modes) and the moderately strong carbonyl signal at $1620 \mathrm{~cm}^{-1}$, assigned to the carboxylic group, and in particular the asymmetric stretching mode. Although some bands might be hidden by the calcite bands, most of the typical signals are clearly evident. A study of the literature enabled us to recognize a plant gum, possibly gum arabic. The peaks around $1070 \mathrm{~cm}^{-1}$, often present in the samples, could be assigned to $\beta-(1 \rightarrow 6)$ and $\beta-(1 \rightarrow 3)$-linked-galactan; that is, polymerized galactose, the basic unit of gum arabic (Renard et al. 2006). Also, the peaks around 1420-1450 $\mathrm{cm}^{-1}$, present in some cases, probably indicate $\mathrm{COO}$ - asymmetric stretching of the compound. The aging of gum arabic initiates a new, weak absorbance at $1730 \mathrm{~cm}^{-1}$, due to oxidation reactions, which was sometimes observed in the samples (Caruso 2006).

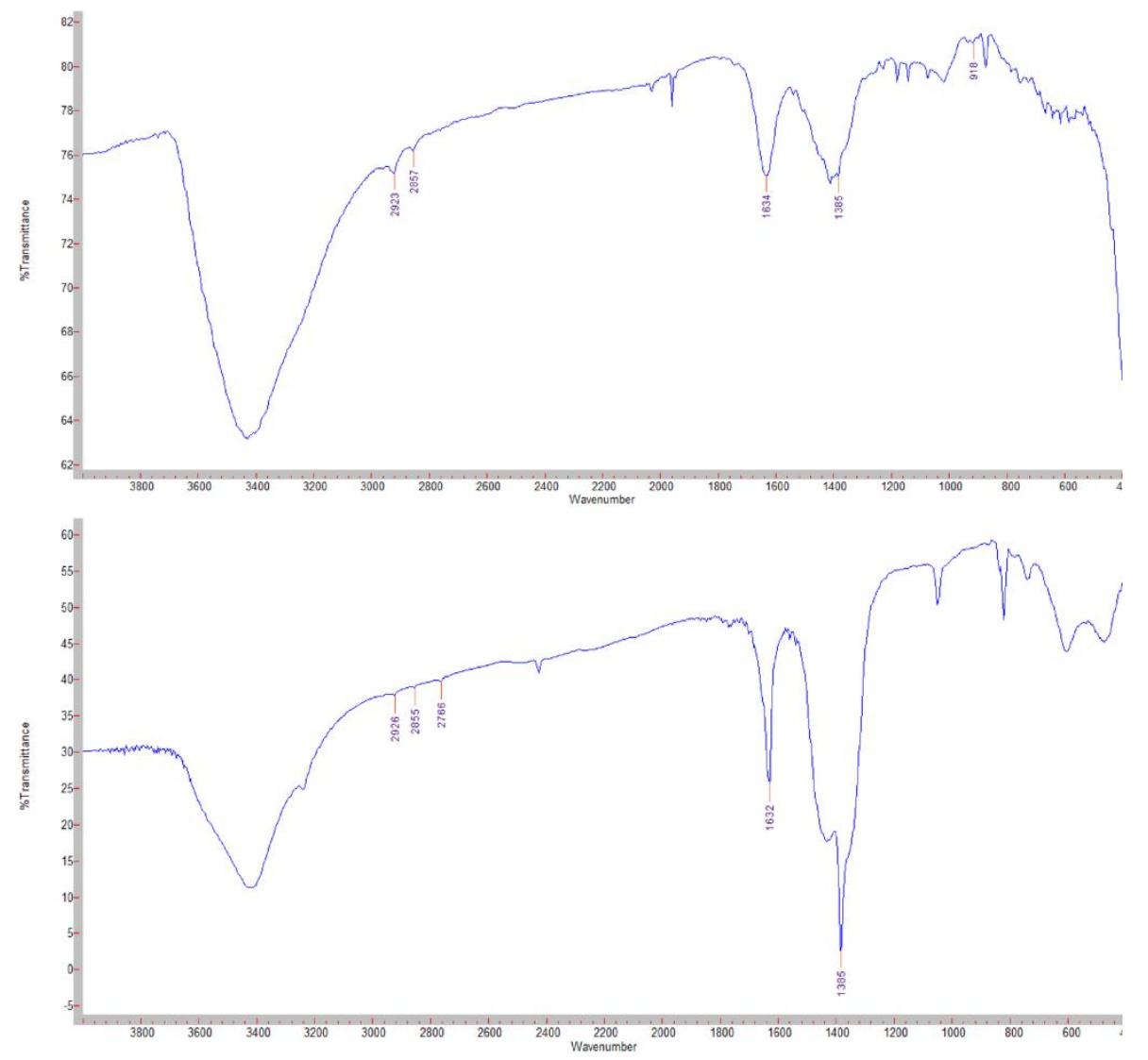


Due to natural and anthropic decay, only very low amounts of organic matter are generally recovered in ancient works of art. Thus, only the samples (A7, A8, A11, A15, A23 and A27) that after extraction with ethyl acetate showed the strongest diagnostic peaks belonging to organic compounds-for example, signals around 2900, 2800, 1730, 1630, 1230 and $1070 \mathrm{~cm}^{-1}$ - were selected for GC-MS analyses, in order to have the best chance of determining their nature.

Gas chromatography - mass spectrometry analysis (GC-MS) There was no proteinaceous or lipid material in any of the samples, which showed a content below the limit of detection (LOD) of the procedure; however, the saccharide content was above the LOD of the procedure. The chromatogram of the saccharide fraction of sample A15 is presented in Figure 6, as an example of the chromatographic profiles obtained from the samples. Table 3 shows the relative percentage sugar composition, as well as the saccharide content, calculated as the sum of the nine sugars quantified, for all samples. The glycoside profiles reveal several sugars, suggesting that a polysaccharide material could be present in the samples. The absence of glucose and of peaks corresponding to ketose sugars enables materials such as starch to be ruled out as the additive added to the mortars. However, neither the quantitative nor the qualitative profiles are in agreement with those in the literature for reference materials (Lluveras-Tenorio et al. 2012a). Given the high content of inorganic material, responsible for the modification of sugar profiles (Lluveras-Tenorio et al. 2012b), the low percentage of organic material in each of the samples in terms of the total amount of sample analysed (around $0.01 \%$ ) and the absence of other organic materials (e.g., proteinaceous) that could contribute to the saccharide profile (LluverasTenorio et al. 2012b), it is not possible to identify the source of the saccharide material present in the samples. However, as both aldoses and uronic acids were present, the glycoside profiles seem to point to the presence of a polysaccharide material of plant origin.

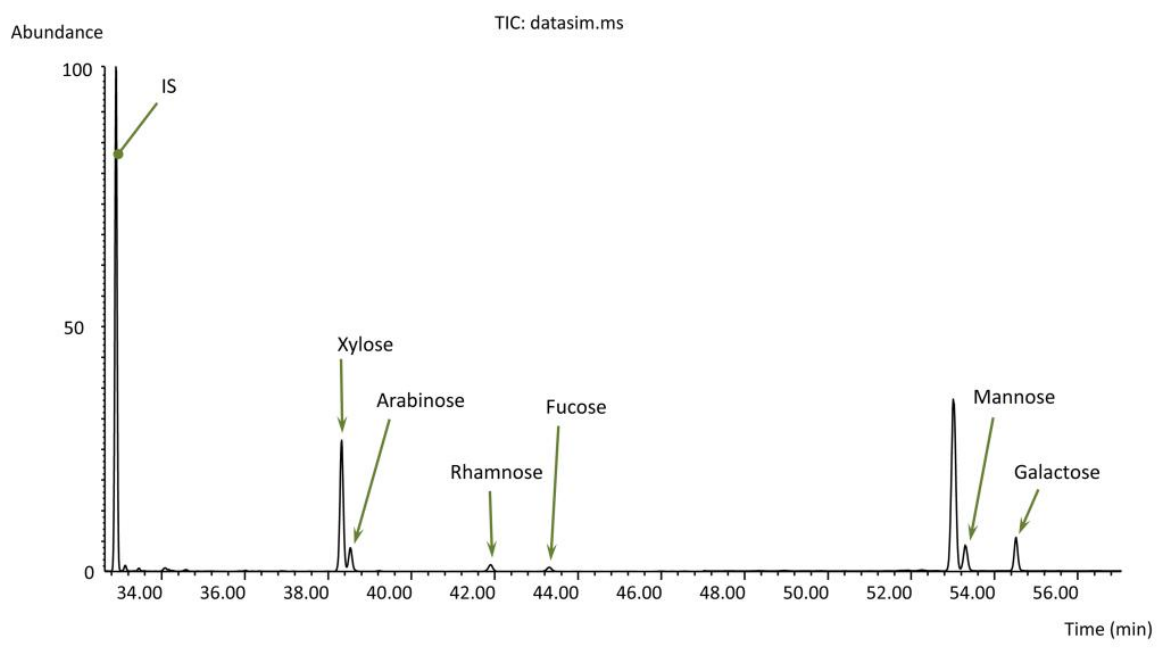

Figure 6 A chromatogram in single ion monitoring (SIM) of the saccharide fraction of sample A15. IS, internal standard mannitol. 


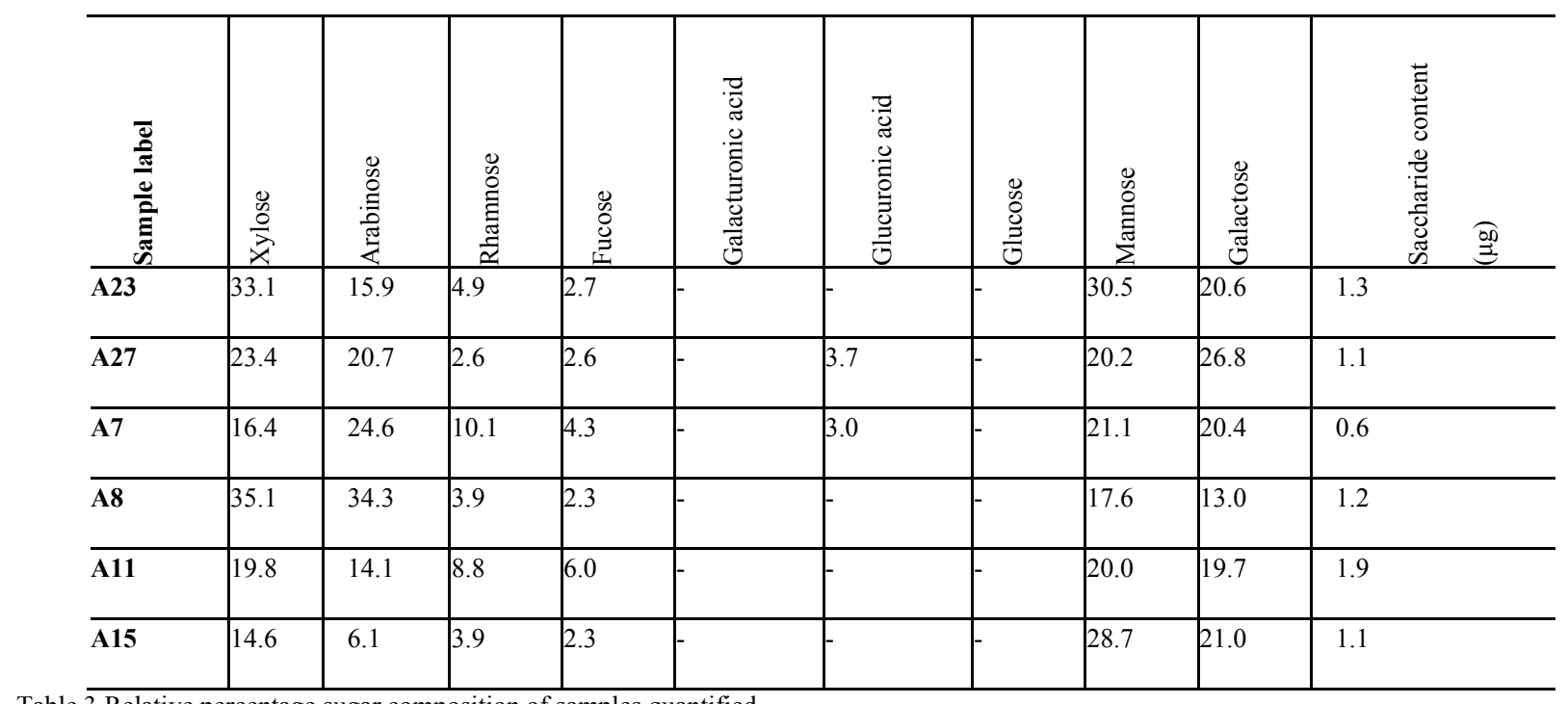

Table 3 Relative percentage sugar composition of samples quantified.

Thermogravimetric analysis (TGA) Thermal analysis may also reveal the presence of natural gums, by the weight losses around $90^{\circ} \mathrm{C}$ and $320^{\circ} \mathrm{C}$, respectively due to water loss and polysaccharide depolymerization (Zohuriaan and Shokrolahi 2004). The investigation was carried out on the same samples as analysed by GC-MS, confirming the presence of gum. In particular, a weight loss was observed around $340^{\circ} \mathrm{C}$. The signal was weak, as the organic fraction was expected to be a minor component of the mortar sample. Figure 7 shows the TG/DSC curve of sample A23. The differential scanning calorimetry (DSC) thermogram shows a peak around $300^{\circ} \mathrm{C}$, which may be associated with the exothermic transition typical of the depolymerization of natural gums (Zohuriaan and Shokrolahi 2004).

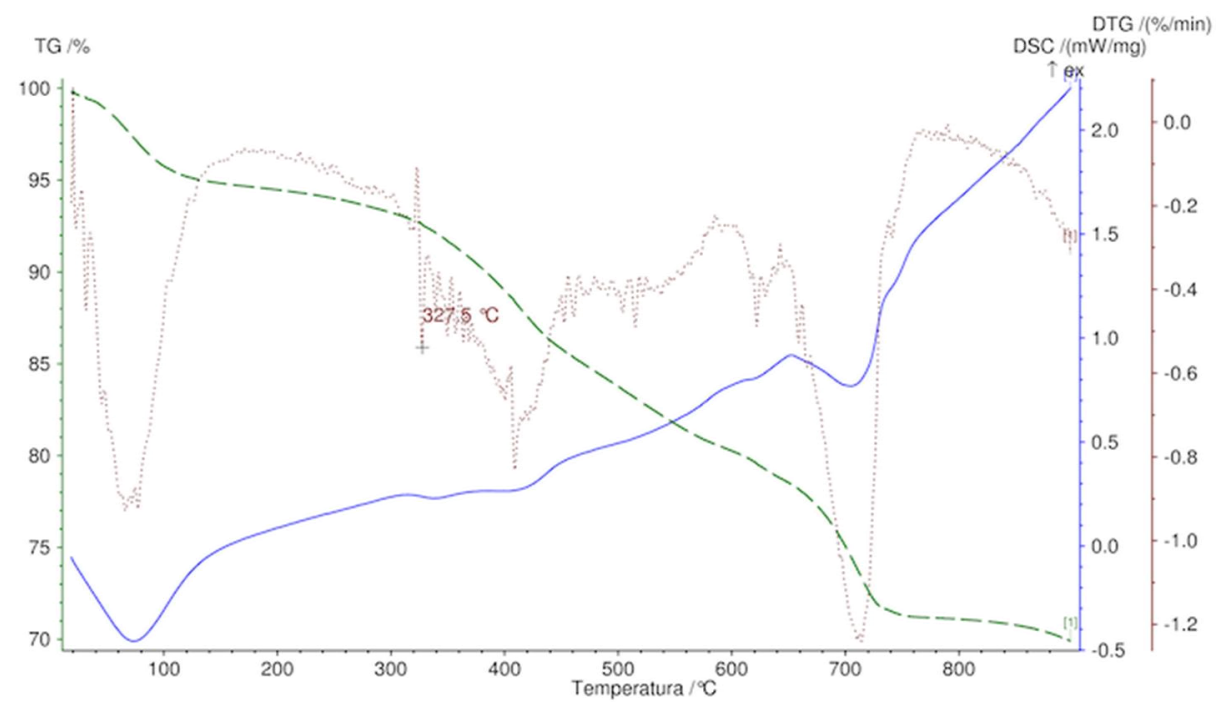

Figure 7 A thermogravimetric analysis and differential scanning calorimetry (TG/DSC) thermogram of sample A23, showing the DSC peak of depolymerization of natural gums at $340^{\circ} \mathrm{C}$. Weight losses at 67,410 and $712^{\circ} \mathrm{C}$ are due to water loss, organic compounds and CaCO decomposition, respectively. Continuous curve, DSC; long-dashed curve, TG; dotted line, first derivative of TG curve. 


\section{CONCLUSIONS}

The mortars taken from the Arsenale were investigated using both mineralogical and chemical techniques. The mineralogical techniques revealed the minerals were present both in the aggregate and in the binder fractions. The results identified an aerial mortar, where the aggregate phase was made up of volcanic rocks. The presence of halite was due to the proximity to the seashore. The FT-IR analyses were important in determining the organic components and suggesting the presence of a saccharide material, possibly a natural gum. FT-IR confirmed its role as a rapid determination method for the preliminary screening, since the results influenced the choice of confirmatory sensitive analytical techniques, such as GC-MS and TGA. The GC-MS results enabled us to rule out the presence of lipid and proteinaceous materials and to confirm the presence of a saccharide material in all the analysed samples: the glycoside profiles were in agreement with the presence of a polysaccharide material of plant origin. The TGA investigations also revealed the presence of a natural gum, thus indicating the use of organic additives to strengthen the mixture and confirming the mortar recipes for the historical masonry. This study demonstrates that the presence of organic additives can be detected even if the mortar is rough and no clues are perceivable in its texture, due to its rough appearance. In fact, very often there are organic additives when a smooth and partially glossy surface is visible. This is often the case for stuccowork or mortars applied as a final render. Thus, evidence of organic additives in a mortar bedding is considered quite unique.

\section{ACKNOWLEDGEMENTS}

The authors would like to thank Professor Giuseppe Gargano for valuable discussions and Dr Roberto Mauri for the sketch of the Arsenale.

\section{REFERENCES}

Alonso, E., Martinez-Gomez, L., Martinez,W., and Castano, V. M., 2002, Preparation and characterisation of ancientlike masonry mortars, Advanced Composites Letters, 11, 33-6.

Arcolao, C., 1998, Le ricette del restauro: malte, intonaci, stucchi dal XV al XIX secolo, Marsilio, Venezia.

Bugini, R., Folli, L., Corti, C., and Rampazzi, L., 2014, Features of a Roman clay plaster (Brixia, Lombardy, Italy), in Proceedings of the International Symposium on Archaeometry, 19-23 May 2014, Los Angeles.

Bugini, R., Della Torre, S., Pozzi, A., Rampazzi, L., and Sansonetti, A., 2006, Classification of multi-layered plasters from St. Abbondio Cloister in Como (Italy): an analytical tool for building archaeology, Materiales de Construccion, 282, 5-16.

Carbonara, G., 2007, Trattato di restauro architettonico, vols I and II, UTET, Roma. 
Cardenas, A., Arguelles, W. M., and Goycoolea, F. M., 1998, On the possible role of Opuntia ficus-indica mucilage in lime mortar performance in the protection of historical buildings, Journal of the Professional Association for Cactus Development, 3, 64-71.

Caruso, S., 2006, Caratterizzazione ed invecchiamento di leganti pittorici a base di gomme vegetali, Università degli Studi di Torino.

Cennini, C., 2009, Il libro dell'arte, Neri Pozza, Vicenza.

Chandra, S., Eklund, L., and Villarreal, R. R., 1998, Use of cactus in mortars and concrete, Cement and Concrete Research, 28, 41-51.

CNR-ICR, 1980, Raccomandazione Normal 3/80: Materiali lapidei: campionamento, CNR-ICR, Rome.

Colombini, M. P., Ceccarini, A., and Carmignani, A., 2002, Ion chromatography characterization of polysaccharides in ancient wall paintings, Journal of Chromatography A, 968(1-2), 79-88.

Colombini, M. P., Giachi, G., Modugno, F., Pallecchi, P., and Ribechini, E., 2003, The characterization of paints and waterproofing materials from the shipwrecks found at the archaeological site of the Etruscan and Roman harbour of Pisa (Italy), Archaeometry, 45, 659-74.

Corti, C., Rampazzi, L., Bugini, R., Sansonetti, A., Biraghi, M., Castelletti, L., Nobile, I., and Orsenigo, C., 2013, Thermal analysis and archaeological chronology: the ancient mortars of the site of Baradello (Como, Italy), Thermochimica Acta, 572, 71-84.

Cui, S.W., Phillips, G. O., Blackwell, B., and Nikiforuk, J., 2007, Characterisation and properties of Acacia senegal (L.) Willd. var. senegal with enhanced properties (Acacia (sen) SUPERGUMTM): Part 4. Spectroscopic characterisation of Acacia senegal var. senegal and Acacia (sen) SUPERGUMTM arabic, Food Hydrocolloids, 21, 347-52.

Derrick, M., 1989, Fourier transform infrared spectral analysis of natural resins used in furniture finishes, Journal of the American Institute for Conservation, 28(1), 43-56.

Derrick, M. R., Stulik, D., and Landry, J. M., 1999, Infrared spectroscopy in conservation science, The Getty Conservation Institute, Los Angeles, CA.

Doménech Carbó, M. T., Bosch Reig, F., Gimeno Adelantado, J. V., and Periz Martinez, V., 1996, Fourier transform infrared spectroscopy and the analytical study of works of art for purposes of diagnosis and conservation, Analytica Chimica Acta, 330, 207-15.

Duran, A., Robador, M. D., Jimenez de Haro, M. C., and Ramirez-Valle, V., 2008, Study by thermal analysis of mortars belonging to wall paintings corresponding to some historical buildings of Sevillian art, Journal of Thermal Analysis and Calorimetry, 92(1), 353-59. 
Gargano, G., 1994, Fortificazioni e marineria in Amalfi angioina, Rassegna del Centro di Cultura e Storia Amalfitana, 14(7/8), 73-133.

Krizkova, M. C., Kuckova, S. H., Santrucek, J., and Hynek, R., 2014, Peptide mass mapping as an effective tool for historical mortar analysis, Construction and Building Materials, 50, 219-25.

Kuckova, S., Hynek, R., and Kodicek, M., 2009, Application of peptide mass mapping on proteins in historical mortars, Journal of Cultural Heritage, 10(2), 244-7.

Kurugol, S., and Gulec, A., 2012, Physico-chemical, petrographic, and mechanical characteristics of lime mortars in historic Yoros Castle (Turkey), International Journal of Architectural Heritage, 6(3), 322-41.

Lluveras, A., Bonaduce, I., Andreotti, A., and Colombini, M. P., 2010, GC/MS analytical procedure for the characterization of glycerolipids, natural waxes, terpenoid resins, proteinaceous and polysaccharide materials in the same paint microsample avoiding interferences from inorganic media, Analytical Chemistry, 82(1), 376-86.

Lluveras-Tenorio, A., Mazurek, J., Restivo, A., Colombini, M. P., and Bonaduce, I., 2012a, Analysis of plant gums and saccharide materials in paint samples: comparison of GC-MS analytical procedures and databases, Chemistry Central Journal, 6, 115.

Lluveras-Tenorio, A., Mazurek, J., Restivo, A., Colombini, M. P., and Bonaduce, I., 2012b, The development of a new analytical model for the identification of saccharide binders in paint samples, PLOS ONE, 7(11), e49383.

Luxan, M. P., Dorrego, F., and Laborde, A., 1995, Ancient gypsum mortars from St. Engracia (Zaragoza, Spain)characterization-identification of additives and treatments, Cement and Concrete Research, 25(8), $1755-65$.

Pecchioni, E., Fratini, F., and Cantisani, E., 2008, Le malte antiche e moderne tra tradizione e innovazione, Patron Editore, Bologna.

Pliny, 1968, Natural history, Harvard University Press, Cambridge, MA.

Rampazzi, L., and Bugini, R., 2006, Integrated approach to the characterisation of historical mortars: the case study of St. Lorenzo Basil in Milan, e-Preservation Science, 3, 21-6.

Rampazzi, L., Corti, C., Colombo, C., Conti, C., and Realini, M., 2010, Development of an analytical protocol for the characterisation of historical mortars, in Proceedings of the 2nd Historic Mortars Conference, Prague, 22-24 September 2010. 
Rampazzi, L., Rizzo, B., Colombo, C., Conti, C., Realini, M., Bartolucci, U., Colombini, M. P., Spiriti, A., and Facchin, L., 2012, The stucco technique of the Magistri Comacini: the case study of St. Maria dei Ghirli in Campione d'Italia (Como, Italy), Archaeometry, 54, 926-39.

Rampazzi, L., Rizzo, B., Colombo, C., Conti, C., Realini, M., Bartolucci, U., Colombini, M. P., Spiriti, A., and Facchin, L., 2008, The stuccoes of St. Lorenzo in Laino (Como, Italy): the materials and the techniques employed by the 'Magistri Comacini', Analytica Chimica Acta, 630, 91-100.

Renard, D., Lavenant-Gourgeon, L., Ralet, M.-C., and Sanchez, C., 2006, Acacia senegal gum: continuum of molecular species differing by their protein to sugar ratio, molecular weight, and charges, Biomacromolecules, 7, $2637-49$.

Sickels, L.-B., 1981, Organics vs. synthetics: their use as additives in mortars, in Mortars, cements and grouts used in the conservation of historic buildings. Symposium, Rome, 3-6 November 1981, 25-52, ICCROM, Rome.

Ventola, L., Vendrell, M., Giraldez, P., and Merino, L., 2011, Traditional organic additives improve lime mortars: new old materials for restoration and building natural stone fabrics, Construction and Building Materials, 25, $3313-18$.

Vitruvius, 1999, Ten books on architecture, Cambridge University Press, New York.

Zeng, Y., Zhang, B., and Liang, X., 2008, A case study and mechanism investigation of typical mortars used on ancient architecture in China, Thermochimica Acta, 473(1-2), 1-6.

Zohuriaan, M. J., and Shokrolahi, F., 2004, Thermal studies on natural and modified gums, Polymer Testing, 23, 575-9. 